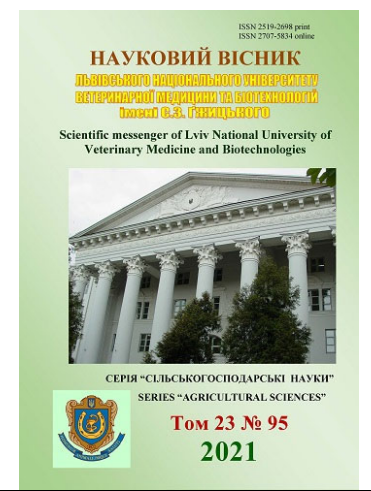

Науковий вісник Дьвівського національного університету ветеринарної медицини та біотехнологій імені С.3. Гжицького. Серія: Сільськогосподарські науки

\author{
Scientific Messenger of Lviv National University \\ of Veterinary Medicine and Biotechnologies. \\ Series: Agricultural sciences
}

doi: 10.32718/nvlvet-a9510

https://nvlvet.com.ua/index.php/agriculture

UDC 638.19:638.1:633.31

\title{
The influence of feed quality on the development and productivity of bee queens
}

\author{
Yu. Kovalskyi, B. Gutyj, V. Fedak, L. Kovalska, A. Druzhbiak \\ Stepan Gzhytskyi National University of Veterinary Medicine and Biotechnologies Lviv, Ukraine
}

Article info

Received 10.05.2021

Received in revised form 14.06.2021

Accepted 15.06.2021

Stepan Gzhytskyi National University of Veterinary Medicine and Biotechnologies Lviv,

Pekarska Str., 50, Lviv,

79010, Ukraine.

Tel.:+38-067-938-54-13

E-mail:prikarpatmed@ukr.net
Kovalskyi, Yu., Gutyj, B., Fedak, V., Kovalska, L., \& Druzhbiak, A. (2021). The influence of feed quality on the development and productivity of bee queens. Scientific Messenger of Lviv National University of Veterinary Medicine and Biotechnologies. Series: Agricultural sciences, 23(95), 7175. doi: $10.32718 /$ nvlvet-a9510

The research aimed to study the effect of additional protein feeding of foster families with buckwheat stalks. The research was conducted during the summer period in 2020 and 2021. Ten foster families were selected for the experiment. All families are chosen by the method of analogs. Bees were kept in beehives. The uterus of the Carpathian breed took part in the investigation. Control families were fed $200 \mathrm{~g}$ of sugar syrup (1:1) twice daily for 8 and 21 hours. Feeding began three days before inoculation of queen cells and continued until the time of their sealing. The experimental families were fed the same amount of sugar syrup. Still, they received an additional $0.5 \mathrm{~kg}$ of protein feed in the form of bee pollen from buckwheat, the average protein content of which was $22.0 \pm 0.32 \%$. Bee pollen is obtained by selection with the help of mounted on the auxiliary families of hinged pollen catchers with a diameter of the inlet of the pollen catcher lattice $5 \mathrm{~mm}$. Pruning was carried out during the flowering of buckwheat in the period from morning to 13 $o^{\prime}$ clock in the afternoon. Adding bee pollination to the feed of foster families improves the growth and development of queens. Balancing the diet by nutrients increases the reproductive performance of the uterus, which is directly proportional to the level of their protein supply. When growing queens, the introduction of additional protein components of feed into the diet of foster families in the form of buckwheat leads to an increase in the maximum load of honeycomb by $11.4 \%$. The level of development of the pharyngeal glands in the researcher's families was $49 \%$ higher. Balancing the diet by nutrients increases the reproductive performance of the queens of the Carpathian breed of bees by $16 \%$ compared to the control.

Key words: buckwheat bee corbicula, foster families, infertile queens, worker bees, royal jelly.

\section{Вплив якості корму на розвиток і продуктивність бджолиних маток}

\author{
Ю. В. Ковальський, Б. В. Гутий, В. В. Федак, Л. М. Ковальська, А. Й. Дружбяк
}

Львівський національний університет ветеринарної медицини та біотехнологій імені С. 3. Гжсиького, м. Львів, Україна

Метою проведених досліджень було вивчення впливу додаткової білкової підгодівлі сімей-виховательок обніжжям гречки. Дослідження проводили протягом літнього періоду в 2020 та 2021 роках. Для досліду було відібрано 10 сімей-виховательок. Усі сім' $і$ підібрані за методом аналогів. Бджіл утримували у вуликах-лежаках. У досліді брали участь матки карпатської породи. Контрольним сім'ям протягом доби двічі згодовували по 200 г иукрового сиропу (1:1) у 8 та 21 год. Підгодівлю починали за три доби до прищеплення маточників і продовжували до часу їх запечатування. Дослідні сім'ї підгодовували такою ж кількістю иукрового сиропу, але крім того, вони отримали додатково по 0,5 кг білкового корму у вигляді бджолиного обніжжя з гречки, середній вміст протеїну якого становив 22,0 0 0,32\%. Бджолине обніжжя отримане иляхом відбору за допомогою встановлених на допоміжних сім'ях навісних пилковоловлювачів із діаметром вхідного отвору пилковловлюваної решітки 5 мм. Збір обніжжя проводили під час цвітіння гречки у часовий проміжок від ранку до 13 години дня. Додавання до корму сімей-виховательок бджслиного обніжжя поліпшує ріст і розвиток маток. Балансування раціону за поживними речовинами підвищує репродуктивні показники маток, які прямо пропориійно пов'язані з рівнем їхнього білкового забезпечення. При вирочуванні маток внесення додаткових білкових складників корму до раціону сімей-виховательок у вигляді обніжжя гречки призводить до збільшення показників максимального наван- 
таження медового зобика на 11,4\%. Рівень розвитку глоткових залоз у дослідних сім'ях був на $49 \%$ більшим. Балансування раціону за поживними речовинами збільшує репродуктивні показники маток карпатської породи бджіл на $16 \%$ порівняно з контролем.

Ключові слова: бджолине обніжж, сім ӥ-виховательки, неплідні матки, робочі бджоли, маточне молочко.

\section{ВстуII}

Під якістю матки перш за все розуміють їі можливість відкладати максимальну кількість життєздатних яєць (Avetisjan, 1983; Gubin, 1984; Davydenko et al., 1992). Деякі науковці встановили пряму залежність між розмірами тіла матки та розвитком іiі яєчників, кількістю в них яйцевих трубок і відповідно - іiі плодючістю. Велика за розмірами матка здатна відкладати якнайбільшу кількість яєць, що протягом сезону сягає 150-200 тис. шт. (Moskalenko, 1983; Lebedev \& Bilash, 1991). Визначальним чинником, який впливає на ці показники, є аліментарний фактор (Hubskyi, 2000). Застосування додаткової підгодівлі у медоносних бджіл призводить до поліпшення перебігу фізіолого-біохімічних процесів в їхньому організмі (Kovalskyi et al., 2018; Kovalchuk et al., 2019; Kovalskyi et al., 2021). Особливо чіткі ознаки впливу якості корму виявляються в процесі росту і розвитку маток. Нестача пергових запасів на матковивідних пасіках може спричинити значні втрати внаслідок того, що сім'ї-виховательки погано прийматимуть маточні личинки на вирощування. Крім того, годівля бджіл незбалансованими кормами призводить до народження неякісних маток, які не відповідають очікуваним господарсько-корисним ознакам (Polishchuk, 2001; Vishchur et al., 2016; Fröhlich et al., 2020). Тому актуальним питанням на племінних пасіках є забезпечення бджіл білковими кормами, а також застосування їх замінників. На думку деяких аналітиків, на якість матки вливають понад 40 чинників (Buhera, 2001; Groh et al., 2004; Harano, 2013). На деякі з цих факторів можна впливати та коректувати, застосовуючи ту чи іншу технологію вирощування маток.

Тому метою проведених досліджень було вивчення впливу додаткової білкової підгодівлі сімейвиховательок обніжжям гречки.

\section{Матеріал і методи досліджень}

Дослідження проводили протягом літнього періоду в 2020 та 2021 роках. Для досліду було відібрано 10 сімей-виховательок. Усі сім'ї підібрані за методом аналогів. Бджіл утримували у вуликах-лежаках. У досліді брали участь матки карпатської породи. Контрольним сім'ям протягом доби двічі згодовували по 200 г цукрового сиропу $(1: 1)$ у 8 та 21 год. Підгодівлю починали за три доби до прищеплення маточників і продовжували до часу їх запечатування. Дослідні сім’ї підгодовували такою ж кількістю цукрового сиропу, але крім того, вони отримали додатково по 0,5 кг білкового корму у вигляді бджолиного обніжжя 3 гречки, середній вміст протеїну якого становив $22,0 \pm 0,32 \%$. Бджолине обніжжя отримане шляхом відбору за допомогою встановлених на допоміжних сім'ях навісних пилковоловлювачів із діаметром вхідного отвору пилковловлюваної решітки 5 мм. Збір обніжжя проводили під час цвітіння гречки у часовий проміжок від ранку до 13 години дня (Kuprijanova \& Al'oshina, 1978). Для споживання бджолами корм засипали в стільники і підставляли у гніздо біля кормової рамки. Пасіка благаполучна щодо заразних хвороб.

Матеріалом для дослідження були робочі особини бджолиних сімей і матки. Після виходу бджіл з комірок їх зважували, відпрепаровували хоботки, тергіти і стерніти та вимірювали їхню довжину і ширину. Максимальне навантаження медового зобика визначали у відловлених бджіл, які прилітали до вулика, шляхом його зважування разом з вмістом. Зміни фізіологічного стану глоткової залози встановлювали за рівнем іiі розвитку, який визначали гістологічним методом за Мауріціо А. (Maurizio, 1954). Для цього зрізали шар фронтальної частини головної капсули, після чого глоткову залозу відпрепаровували і розправляли на предметному склі в краплі дистильованої води. Оскільки в розвитку правої і лівої гілок глоткової залози інколи спостерігаються невеликі відмінності, то оцінювали обидві частини. Рівень розвитку слинних залоз досліджували під мікроскопом (при 100кратному збільшенні) та оцінювали за 4-ступеневою шкалою Геса (Maurizio, 1954).

1-й ступінь: головний і бокові канали добре видно; залозисті альвеоли недорозвинені, неправильної форми, прозорі, часто утворюють вузлики.

2-й ступінь: видно головний вивідний і бокові канали; альвеоли неправильної округлої форми з чітко вираженими проміжками, прозорі.

3-й ступінь: вивідний і бокові канали більшою частиною закриті набряклими альвеолами. Альвеоли частково прозорі, розміщені з невеликими проміжками одна від одної.

4-й ступінь: вивідний і бокові канали зовсім закриті, між альвеолами не видно ніяких проміжків. Альвеоли досягають максимального розвитку, вони молочно-білого або жовтуватого кольору, здатні виділяти молочко.

Маточне молочко 3 маточників відбирали згідно 3 технологічними прийомами виведення неплідних маток методом Пратта-Дулітля (Brovarskyi \& Bahrii, 1995).

Вірогідність різниці між середньоарифметичними даними оцінювали за критеріями Стьюдента (Plohinskij, 1969).

\section{Результати та їх обговорення}

При споживанні білкового корму у вигляді бджолиного обніжжя гречки у бджіл-годувальниць збільшуються не тільки лінійні розміри тіла, а й у їхньому організмі відбуваються позитивні процеси, що виявляються у кращому розвитку ацинусів слинних залоз. Забезпечення маточної личинки достатньою кількістю маточного молочка в період іiі 
росту $є$ фундаментальною складовою одержання якісних маток.

Згідно $з$ результатами проведених досліджень, підгодівля сімей-виховательок обніжжям гречки не викликало значного збільшення маси бджілгодувальниць (табл. 1).

\section{Таблиця 1}

Зміни характерних показників росту і розвитку бджіл-годувальниць залежно від складу раціону $(\mathrm{M} \pm \mathrm{m}, \mathrm{n}=10)$

\begin{tabular}{lrr}
\hline \multicolumn{1}{c}{ Показник } & \multicolumn{2}{c}{ Сім’ї-виховательки } \\
\cline { 2 - 3 } Маса бджоли, мг & контрольні & дослідні \\
\hline Довжина хоботка, мг & $98,3 \pm 5,77$ & $101,2 \pm 9,63$ \\
Максимальне навантаження медового зобика, мг & $6,6 \pm 1,84$ & $6,7 \pm 1,25$ \\
Ступінь розвитку глоткових залоз, балів & $51,8 \pm 1,21$ & $58,5 \pm 2,96 *$ \\
\hline
\end{tabular}

Примітка: тут і надалі: *-P <0,05; **- $\mathrm{P}<0,01 ; * * *-\mathrm{P}<0,001$

У контрольних сім'ях середня маса бджіл складала $98,3 \pm 5,77$ мг, тим часом як у дослідних сімей цей показник зріс до 101,2 \pm 9,63 мг. Згідно з даними деяких фахівців, маса тіла бджіл є величиною, яка прямо-пропорційно пов'язана 3 тривалістю життя бджіл і ступенем розвитку жирового тіла. Аналогічні дані отримано щодо деяких морфометричних показників екстер'єру. Зокрема при дослідженні довжини хоботка встановлено, що годівля бджіл запропонованим способом не спричиняла значних змін його розмірів. У піддослідних сімей довжина хоботка коливалась в межах від 6,6 до 6,7 мм.

Проведені дослідження вказують на зміни інтер'єрних показників робочих особин. Так, у бджіл дослідних сімей збільшився об'єм медового зобика. При додатковій годівлі обніжжям гречки максимальне навантаження медового зобику становило 58,5 мг, що на $11,4 \%(\mathrm{P}<0,05)$ є більшим порівняно $з$ бджолами контрольної групи. Збільшення об'єму медового зобика призводить до зростання продуктивності сімей.

Гіпофарингіальна залоза бджоли, що тільки вийшла 3 комірки, не розвинена. Однак уже 3 перших днів життя, за умов повноцінного живлення, насамперед білкового, залоза починає розвиватися - збільшуються в розмірах альвеоли, з'являються везикули з секретом. У 9-12-добовому віці глоткова залоза досягає максимального розвитку. 3 віком секреторна активність залози знижується. Гіпофарингіальна залоза робочих бджіл виділяє секрет, що входить до складу молочка для годування личинок. Окрім того, вона виділяє також інвертазу - ензим, який бере участь у розщепленні складних цукрів нектару на прості. Відсутність білкового корму в раціоні при вирощуванні маток негативно впливає на процеси, пов'язані з розвитком слинних залоз. Особливо це явище проявляється при дослідженні розвитку глоткових залоз бджіл. Адже відомо, що саме ці залози відповідальні за секрецію маточного молочка і власне вони беруть участь у вигодовуванні маточних личинок. Проведеними дослідженнями встановлено, що внаслідок додаткового споживання пилку ступінь розвитку глоткових залоз у бджіл збільшується на 49,0 \% ( $>$ < 0,001). Споживання винятково цукрового сиропу не викликає секреторної активності клітин залоз. У бджіл, що живилися лише одним медом, тільки в окремих випадках з'являються секретуючі клітини.
Аналізуючи вплив кормового фактора, можна стверджувати, що кількість маточного молочка у маточниках прямо пропорційна ступеню розвитку гіпофарингіальних залоз бджіл-годувальниць у сім'яхвиховательках (рис. 1). Причому вміст протеїну в раціоні сім'ї-виховательки не повинен бути меншим за $20 \%$.

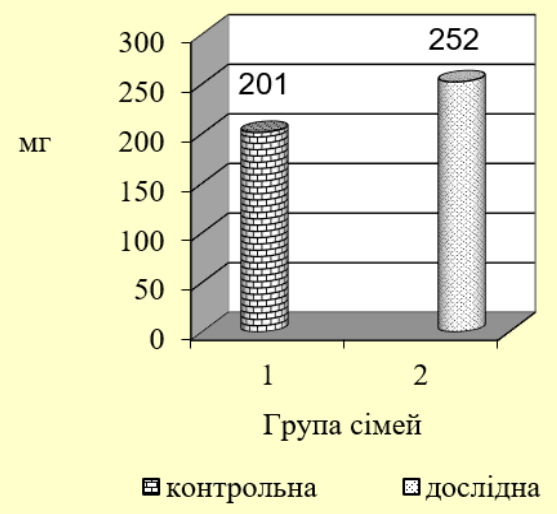

Рис. 1. Маса маточного молочка з одного маточника залежно від якості годівлі $(\mathrm{n}=30)$

У дослідних сімей середня маса маточного молочка, отриманого з одного маточника, становила $252 \pm 2,3$ мг, тимчасом як у контрольних сімей цей показник був на рівні $201 \pm 1,3$ мг, що на 30,3\% менше. Такі позитивні зміни зумовлені тим, що під час росту і дозрівання маточних личинок вони мали кращі умови догляду. При додатковому живленні білковими складниками корму в робочих бджіл виявлено збільшення морфометричних показників ацинусів. Як наслідок - синтез маточного молочка відбувається інтенсивніше.

Дослідження процесу оогенезу вказує на те, що саме в період росту відбувається формування яйцевих трубочок у яєчниках матки. У процесі проведених досліджень матки не вирізнялися високою інтенсивністю відкладання яєць, оскільки сила бджолиних сімей не була на тому рівні, при якому проявляються біологічні особливості карпатських маток. При споживанні корму, збагаченого білковими компонентами, динаміка вирощування розплоду у дослідних сімей зазнала позитивних змін порівняно 3 контролем. Так, при першому вимірюванні (станом на 28 червня) зафіксовано середньодобову яйцекладку маток дослідних 
сімей на рівні 1254,2 \pm 79,63 шт. Це на $4 \%$ більше порівняно 3 матками контрольної групи $(\mathrm{P}<0,01)$. Однак два наступні вимірювання середньодобової яйцекладки показали, що у маток дослідних сімей інтенсивність відкладання яєць на $16 \%(\mathrm{P}<0,1) \epsilon$ більшою. Найбільш яскраво виражена різниця у кількості розплоду при вимірюванні, яке було проведене 2 серпня. Матки, які були вирощені при додаванні до раціону обніжжя гречки, показали кращі показники щодо кількості відкладених яєць. Такий висновок ми можемо зробити при аналізі середньодобової яйцекладки на початку серпня. 3 даних, наведених у таблиці 2, випливає, що репродуктивні показники маток контрольних сімей на 33 \% поступалися дослідним $(\mathrm{P}<0,01)$.

\section{Таблиця 2}

Вплив якості раціону на інтенсивність відкладання яєць матками у піддослідних сім’ях, шт. (M \pm m, $\mathrm{n}=10)$

\begin{tabular}{lccc}
\hline \multirow{2}{*}{ Дата проведення дослідження } & \multicolumn{2}{c}{ Середньодобова яйцекладка } & \multirow{2}{*}{ У \% до контролю } \\
\cline { 2 - 3 } 28 червня & контрольні & дослідні & 104,0 \\
09 липня & $1205,3 \pm 5,77$ & $1254,2 \pm 79,63 * *$ & 116,9 \\
21 липня & $1034,4 \pm 18,84$ & $1209,7 \pm 31,25 *$ & 116,6 \\
02 серпня & $981,8 \pm 10,21$ & $1145,5 \pm 12,96$ & 133,4 \\
Всього & $798,7 \pm 9,21$ & $1066,0 \pm 19,21 * *$ & 116,2 \\
\hline
\end{tabular}

У контрольній групі показник 2 серпня становив $798,7 \pm 9,21$ шт. яєць, що на 33,4 \% менше порівняно 3 дослідною групою.

Варто зауважити, що розплід, який буде вирощений у цей період, братиме участь у вирощуванні генерації бджіл, яка формуватиме основу зимового клубу. Від інтенсивності відкладання яєць в цей період власне і залежить якість майбутньої зимівлі.

Всього за чотири вимірювання матки дослідних сімей відклали в середньому на 16,2 \% більше яєць порівняно $з$ контрольними сім'ями, що свідчить про кращий перебіг обмінних процесів в організмі маток.

\section{Висновки}

Рівень білкового забезпечення сімей-виховательок карпатської породи бджіл позитивно впливає на розвиток усіх особин бджолиної сім'ї. Виявлено позитивну динаміку морфологічних інтер'єрних та екстер'єрних показників неплідних маток. Внаслідок внесення додаткових білкових складників корму до раціону сімей-виховательок у вигляді обніжжя гречки виявлено збільшення показників максимального навантаження медового зобика бджіл-годувальниць на $11,4 \%$. Ступінь розвитку глоткових залоз у бджіл дослідних сімей був на 49 \% більшим. Балансування раціону за поживними речовинами збільшує репродуктивні показники бджолиних маток на 16,2 \% порівняно $з$ контролем.

Відомості про конфлікт інтересів. Автори стверджують про відсутність конфлікту інтересів щодо їхного вкладу та результатів досліджень.

\section{References}

Avetisjan, G. A. (1983). Razvedenie i soderzhanie pchel. Moskva: Kolos (in Russian).

Brovarskyi, V. D., \& Bahrii, I. H. (1995). Rozvedennia ta utrymannia bdzhil. Kyiv: Urozhai (in Ukrainian).
Buhera, S. I. (2001). Osoblyvosti rozvytku ta funktsionuvannia velykoi otruinoi zalozy bdzholynoi matky. Ukrainskyi pasichnyk, 11, 2 (in Ukrainian).

Davydenko, I. K., Mykytenko, H. D., \& Shelak, S. O. (1992). Pleminna robota u bdzhilnytstvi. Kyiv: Urozhai (in Ukrainian).

Fröhlich, B., Tautz, J., \& Riederer, M. (2000). Chemometric Classification of Comb and Cuticular Waxes of the Honeybee Apis Mellifera Carnica. Journal of Chemical Ecology, 26(1), 123-137. doi: 10.1023/A:1005493512305.

Groh, C., Tautz, J., \& Rössler, W. (2004). Synaptic organization in the adult honey bee brain is influenced by brood-temperature control during pupal development. Proc Natl Acad Sci., 101(12), 4268-4273. doi: 10.1073/pnas.0400773101.

Gubin, V. A. (1984). Pokazatel' kachestva matok. Pchelovodstvo, 10, 7-8 (in Russian).

Harano, K. (2013). Effects of juvenile hormone analog on physiological and behavioral maturation in honeybee drones. Apidologie, Springer Verlag, 44 (5), 586-599. doi: 10.1007/s13592-013-0208-7.

Hubskyi, Yu. I. (2000). Biolohichna khimiia. Biolohichna khimiia. Ternopil (in Ukrainian).

Kovalchuk, I., Dvylyuk, I., Lecyk, Y., Dvylyuk, I., \& Gutyj, B. (2019). Physiological relationship between content of certain microelements in the tissues of different anatomic sections of the organism of honey bees exposed to citrates of argentum and cuprum. Regulatory Mechanisms in Biosystems, 10(2), 177181. doi: $10.15421 / 021926$.

Kovalskyi, Y., Fedak, V., Kovalska, L., Druzhbiak, A., \& Vovkun, Y. (2021). Prophylaxis of digestion disorders in honey bees. Scientific Messenger of LNU of Veterinary Medicine and Biotechnologies. Series: Agricultural Sciences, 23(94), 61-64. doi: 10.32718/nvlveta9412.

Kovalskyi, Yu., Gucol, A., Gutyj, B., Sobolev, O., Kovalska, L., \& Mironovych, A. (2018). Features of histolism and hystogenesis in the vital temperature range in the organism of honey bee (Apis mellifera L.) in the postembrional period. Ukrainian Journal of Ecology, 8(2), 301-307. doi: 10.15421/2018_342. 
Kuprijanova, L. A., \& Al'oshina, L. A. (1978). Pyl'ca i spory rastenij flory evropejskoj chasti SSSR. Moskva. T. 1-3 (in Russian).

Lebedev, V. I., \& Bilash, N. G. (1991). Biologija medonosnoj pchely. Moskva VO "Agopromizdat" (in Russian).

Maurizio, A. (1954). Pollernernahrung und Lebensvorgange bei der Honigbiene (Apis Mellifera). Landwertsch. Jahrb. Schweis, 68, 115-182.

Moskalenko, P. G. (1983). Zhirovoe telo i jaichniki v aktivnyj period. Pchelovodstvo, 1, 13 (in Russian).
Plohinskij, N. A. (1969). Rukovodstvo po biometrii dlja zootehnikov. M.: Kolos, 25-27 (in Russian).

Polishchuk, V. P. (2001). Bdzhilnytstvo. Lviv, Ukrainskyi pasichnyk (in Ukrainian).

Vishchur, V. Y., Saranchuk, I. I., \& Gutyj, B. V. (2016). Fatty acid content of honeycombs depending on the level of technogenic loading on the environment. Vìsn. Dnìpropetr. Unìv. Ser. Bìol. Ekol., 24(1), 182187. doi: $10.15421 / 011622$. 